\title{
Challenging Islamist Populism in Indonesia through Catholic Youth Activism
}

\author{
Pam Nilan ${ }^{1, *}$ and Gregorius Ragil Wibowanto ${ }^{2}$ \\ 1 Alfred Deakin Institute for Citizenship and Globalization, Deakin University, Burwood 3125, Australia \\ 2 Department of Sociology, Gadjah Mada University, Sleman 55281, Indonesia; \\ gregorius.ragil.w@mail.ugm.ac.id \\ * Correspondence: pam.nilan@deakin.edu.au
}

check for

updates

Citation: Nilan, Pam, and Gregorius Ragil Wibowanto. 2021. Challenging Islamist Populism in Indonesia through Catholic Youth Activism. Religions 12: 395. https://doi.org/ $10.3390 /$ rel12060395

Academic Editor: Aje Carlbom

Received: 23 April 2021

Accepted: 20 May 2021

Published: 28 May 2021

Publisher's Note: MDPI stays neutral with regard to jurisdictional claims in published maps and institutional affiliations.

Copyright: (c) 2021 by the authors. Licensee MDPI, Basel, Switzerland. This article is an open access article distributed under the terms and conditions of the Creative Commons Attribution (CC BY) license (https:// creativecommons.org/licenses/by/ $4.0 /)$.

\begin{abstract}
This paper reports data from a study of young Catholic activists. They were concerned about the expansion of Islamist populism in democratic Muslim-majority Indonesia. They actively built inter-faith coalitions with local liberal Muslim youth groups and with pan-national Nahdlatul Ulama (NU), the largest independent Islamic organisation in the world. Islamist populism prioritises religious identity over the national identity of citizenship. In framing their citizenship activism against the current tide of Islamist populism, the informants in our study selectively engaged aspects of Catholic theology. They articulated their religious identity as coterminous with a nationalist identity centred on multi-faith tolerance and harmony. That discourse in itself refutes a key principle of Islamist populism in Indonesia, which argues for primordial entitlement.
\end{abstract}

Keywords: Islamist populism; Indonesia; Catholic youth

\section{Introduction}

In anti-colonial movements across the Southeast Asian region, religion has been a driving force of nationalist sentiment. In many cases, the religious identity of the masses drove positive narratives of nationhood as countries strove for independence. Yet in many countries in the region, there are at present minority religious groups within territorial states that struggle against the increased political populism of the religious majority (Liow 2016). The trend towards theocratic populism has been exacerbated by online propaganda and fake news in the era of digital media (Postill 2018). We argue here that "Islamist populism" is widely regarded as a threat to democracy - and to the continued articulation of Pancasila-by numerous constituencies in Indonesia, including the mass Muslim organisations NU and Muhammadiyah (over 140 million members between them). Those constituencies are fighting back against the trend. Catholic youth activists, although small in number, are enjoining that challenge at a grassroots level. They do so in part through making alliances with local moderate Muslim youth and organisations.

It is generally agreed by critical Indonesian scholars that the majority religion of Islam has been widely operationalised for political purposes by populist leaders and groups in Indonesia (e.g., Azra 2020; Haq 2021; Hadiz 2018; Syarif and Hannan 2020; Fanany and Fanany 2021; Harsono 2019). The authors of this paper concur with those views, and we use the familiar phrase-Islamist populism - as an umbrella term to cover that trend. Our usage of the umbrella term Islamist populism acknowledges the wide diversity of Islamic practice and, indeed, Islamism, in Indonesia. As Hefner (2020) points out, there are varieties of Islamism in Indonesia. Some are congruent with democracy and the Pancasila constitution, and some, such as Hizbut-Tahrir, are not. In any case, the paper is not concerned with Islamism as such, but with contestation around Islamist populism in Indonesia.

Our argument here is that the political tool of Islamist populism in Indonesia draws selectively upon some Islamist ideas to suggest to Muslim voters that their political interests are not served by religious pluralism (Azra 2020; Syarif and Hannan 2020; Hadiz 2018; 
Van Bruinessen 2018; Mietzner 2020). It is a form of identity politics. As this special issue illustrates, populism itself is a form of opportunistic identity politics. The logic of that identity discourse is, as in some other Muslim-majority countries, "to create a political constituency based on religious identification, and to exclude groups and individuals who follow allegedly hostile faiths" (Yilmaz and Morieson 2021, p. 4). Hefner (2020, p. 8) maintains that by comparison with other Muslim-majority nations at the time of the Arab uprisings in the early 2010s, Indonesia had developed "civic pluralism of a broadly covenantal sort. In matters of legislation, Islamic education and the all-important question of intellectual leadership and mass-organizational support for democracy and plural citizenship, Indonesia seemed well ahead of most of its Muslim-majority counterparts". However, subsequent public opinion research undertaken by Mietzner and Muhtadi (2019, p. 159) suggests that over half of Indonesian Muslims object to non-Muslims holding senior roles in government, and that intolerance of non-Muslims in public life is growing. That growth appears to be driven by "religio-political entrepreneurs", working through political contestation to move the issue of non-Muslim representation into a central position in public discussions of citizenship (Mietzner and Muhtadi 2019, p. 173). Nevertheless, Schmidt (2021) identifies a powerful push for "Islam Toleran" or "Islam Nusantara"-Islam of the Archipelago-by mass Muslim organisation Nahdlatul Ulama (NU), which had more than 90 million members in 2019. Azra (2020, p. 82) points to the strong influence of the other mass Muslim organisation Muhammadiyah (around 50 million members) in promoting Islam Berkemajuan (Progressive Islam). Both movements aim for an accommodation between state democracy and the practice of Islam (Wahid 2011; Menchik 2019). The two moderate Muslim organisations directly position their own moderate version of Islam against extremist versions of Islam spreading in the country (Pektas 2021).

Eddyono (2020, p. 426) maintains that two forms of nationalism are vying in Indonesia right now. She terms these "citizen-centred nationalism" and "ummah-centred nationalism". In this paper, our use of the generalist term nationalism refers to citizen-centred nationalism, because that is how the term (in Indonesian) was used by the informants. Similarly, our use of the term Islamist populism refers to an ummah-centred nationalism—or, at least, that is how our informants considered it. For the most part, Islamist populist parties-as such - do not do well at the Indonesian ballot box. Nevertheless, that same populist push creates pressure on the two main political parties to focus on Muslim identity platforms.

Indonesia is the largest Muslim-majority democracy in the world, with other religions also present in the nation. The state philosophy, Pancasila, is enshrined in the Preamble of the 1945 Indonesian Constitution. It comprises five principles: (1) belief in one Almighty God; (2) just and civilised humanity; (3) the unity of Indonesia; (4) democracy guided by the wisdom of deliberations among representatives; and (5) social justice. Six religions are officially recognised (Nugroho 2020). Indonesia's first president, Sukarno, intended Pancasila to be a compromise between nationalist and Islamist claims (Vickers 2013). However, a persuasive Islamist populist base has recently emerged which considerably influences the political landscape (Fanany and Fanany 2021; Syarif and Hannan 2020; Harsono 2019). It plays on the deep relationship between perceptions of Islamic piety and the manipulation of public opinion in Indonesia (Pepinsky et al. 2018; Chaplin 2018). Common targets are non-Muslims, Muslims who do not follow the Sunni tradition, and Muslims who permit syncretic practices (Hefner 2011). Hadiz (2018, p. 580) describes Islamist populism in Indonesia today as "a highly illiberal form of democracy, where electoralism reigns but where social rights have often had to take a back seat". For instance, in February 2021, the government finally banned public schools from making religious attire compulsory, after the story of a Christian student being punished for not wearing an Islamic headscarf in class went viral (Soeriaatmadja 2021).

The landscape of struggle for non-Muslim faiths in Muslim-majority Indonesia is complex indeed (Nugroho 2020; Harsono 2019; Menchik 2017). Proportionally, 87.2 per cent of the Indonesian population of 271 million is Muslim, primarily following the Sunni tradition. ${ }^{1}$ Seven per cent are Protestant Christians, and only 2.9 per cent are Roman Catholics 
(IndexMundi 2019). The less-populated eastern islands are predominantly Christian and Catholic (Hariyadi 2019), while Muslims in heavily populated Java and Sumatra make up around 90 per cent of the population. As an ethnic minority in the country, Indonesian Chinese frequently follow the Christian faith (Chong 2018). Although representing less than 10 per cent of total of the Indonesian population, those following Christian/Catholic beliefs are well represented in the ranks of the middle class and the business world in the western islands.

In Java and Sumatra, the Christian/Catholic minority is keen to maintain good relations with the Muslim majority (Hefner 2017, p. 91). They have just as much nationalist pride as other Indonesians and strongly support the unified Indonesian state (Laksana 2015). Even so, the colonialist history of Catholicism in Indonesia is often used by Islamist populists to question the national allegiance of "native-born Catholics" (Rook 2020, pp. 5-6). In Java, Laksana (2018) points out that a Catholic Indonesian identity may be scorned for encoding the colonial past, where indigenous Indonesians embraced the religion of a colonising power, one that had a long-contested history of conflict with Islam in Europe. That constitutes an important background element of the discursive landscape, offline and online, against which young Catholic nationalists frame their counter-populist position. It should be noted that the intermingling of Catholicism and nationalism in some countries of the world has produced very ambiguous, if not negative outcomes, so there is no intention to suggest that it offers a tangible solution to the problems confronting Indonesia. Rather, the synthesis of Catholic identity and nationalist identity has something to tell us about the way political populism is being contested in contemporary Indonesia.

Since the fall of the authoritarian government of Suharto in 1998, Indonesia has been a democratic nation, with open elections (Aspinall 2015). The Indonesian economy has been growing steadily, and the standard of living has risen (Yulisman 2019). In theory, the country continues to follow the original Pancasila philosophy. Pancasila promotes unity in diversity and, within limits, allows freedom of worship. ${ }^{2}$ Yet since 1998, the populist Islamist movement has grown (see Van Bruinessen 2018), and has increasingly threatened Pancasila (Syarif and Hannan 2020). That contestation has undermined democratic gains in the nation (Harsono 2019; Hadiz 2018; Power 2018; Menchik 2017; Hefner 2017). Mietzner (2020, p. 229) nominates five areas of Indonesia's democratic decline in recent years: "populism, increasing religious conservatism, escalating politico-ideological polarisation, worsening political corruption and clientelism, and the growing confidence of anti-democratic elite actors".

The political turmoil fomented by Islamist populism is further complicated by Indonesia's extraordinary religious, ethnic and linguistic diversity, and by its troubled colonial and revolutionary past. There is much concern among ordinary people to avoid confrontation and promote positive social relations. It is generally feared that too much emphasis on religious "freedom" could increase communal conflicts (Marshall 2018, p. 85). Menchik calls this "tolerance without liberalism" (Menchik 2017, p. 124). The preferred terms for religious accommodation are harmony and balance, yet those terms lack a firm definition when faced with strident primordial claims that would deny social justice to others. In Indonesia, Islamist groups apply political pressure for laws and policies that would benefit the perceived interests of the Muslim majority over citizens of religious faiths (Fanany and Fanany 2021; Pedersen 2016). That is a form of theocratic political populism.

\section{Islamist Populism in Indonesia}

Populists strive to appeal to a mass of people in a society who feel their concerns are disregarded by established elite groups. The elite or the establishment is held to be bad in principle, corrupt and disconnected from the lives of everyday people. A populist leader claims to politically represent the unified will of the mass of the people, who are thought to embody some "pure" quality (Mudde and Kaltwasser 2017). Populist discourse assures the masses that, despite their innate superiority, they are under threat from another group (or groups) in society, a constituency constructed as bad, as impure and immoral, as 
responsible for trouble and strife. Nevertheless, in the view of the populists, that minority is allowed to flourish, or is not properly controlled by the morally corrupt establishment and elites (Mudde and Kaltwasser 2017).

Islamist populist rhetoric in Indonesia attempts to mobilise the Muslim-majority population through the provocation and exploitation of emotions- "anger, fear, and rage" (see Yilmaz and Morieson 2021). Salmela and Scheve (2017, p. 571) argue that "affects and emotions play a critical role" in motivating people to support populist movements. In Indonesia, Islamist populism uses perceptions of the international ummah under threat to inflame "ummah nationalism" as previously defined. Those same emotions are then used to construct "us vs. them" binary discourses. As Yilmaz and Morieson $(2021$, p. 10) usefully point out, Indonesian Islamic populism is furthermore couched "in a deeper civilisational frame of reference", one in which Islam is held to define Indonesian culture and identity per se, and therefore "non-Muslims are portrayed as threats to Indonesia". A vital core of populism is the rejection of pluralism (Müller 2021). When populists in a country use religion as a political mobilisation strategy, they construct an exclusionary moral identity against others who do not follow that religion. They employ a "thin" ideology to divide a society simplistically in two (see Mudde and Kaltwasser 2017). Islamist populism in Indonesia identifies the non-Muslim minority as a significant threat (Hadiz 2018). Moreover, it challenges the democratic process of the secular, multi-faith constitution.

Following Bayat (2007) we distinguish the politically-skewed phenomenon of Islamism from the religious faith of Islam. Moreover, we define Islamist populism as a discourse of self-assertion to politically mobilise those Muslims who feel marginalised by the dominant economic, political or cultural processes in their society. As a discourse of reclamation, Islamism offers Muslims a position of "self-respect, self-confidence and a wide-ranging autonomy" (Bayat 2007, p. 7). Islamist populism as a political tool rests on claims regarding the intrinsic moral and cultural purity and superiority of Islam as the only legitimate faith in a nation. The Islamist populist push in the public and political sphere in Indonesia arguably challenges both the democratic process and the constitutional principle of the multi-faith nation enshrined in the Pancasila doctrine (Syarif and Hannan 2020).

Social media are a vital resource for the spread of Islamist populism in Indonesia (Lim 2017). We have seen young Islamists flood popular social media platforms with re-tweeted extremist material from hardline Islamist preachers such as Khalid Basalamah, Felix Siauw and Abdul Somad (Laksana and Wood 2019, p. 1). Scorning the national constitution, hardline Islamist preachers encourage their young followers to push for "the establishment of a caliphate" rather than a democratic state (Marshall 2018, p. 93). They not only excoriate the morally polluting power of the West, but rail against the Indonesian government and the national constitution as well, arguing that Muslims should only be governed by Shari'a law, or at least by (male) Muslims. Sympathisers are promised that the imposition of Shar'ia law would see Indonesia become a religious state and thereby witness God's plan for a moral society unfold on earth. Taking up some features of that exclusionary discourse, Indonesian Islamist populism typically invokes primordialism, whereby Muslim citizens are seen to constitute the sole locus of moral virtue (Syarif and Hannan 2020). In practice, even the mildest versions of Islamist populism rank religious identity over Indonesian national identity. It is precisely that hierarchical configuration of Islamist populism that Catholic youth activists challenge when they prioritise their national identity as citizens over their own religious identity. Muslim youth who endorse a tolerant Islam enact the same kind of challenge.

\section{Indonesian Catholics}

The original inhabitants of the Indonesian islands practiced animism. Hinduism and Buddhism arrived between the second and fourth centuries. Islam was introduced in the thirteenth century. Protestantism was first introduced by the Dutch in the sixteenth century, and the Portuguese first introduced Catholicism around the same time (Arifianto 2009). After the Dutch took colonial control in 1605, Catholics could not worship freely until 
1807, when the political climate changed in Europe. Catholic schools and seminaries were then established (Steenbrink 2015), taking a firm foothold in the eastern islands. Catholic missionary orders followed the global project of evangelisation established by Rome in 1622 (Brown and Tran 2020, p. 197).

From 1897, under the leadership of Frans Van Lith, the mission station in Muntilan near Yogykarta fostered the creation of the first Javanese Catholic intellectuals (Van Klinken 1997). Those intellectuals would later encourage the idea that "to be anti-colonial was part of what it meant to be a Catholic" (Laksana 2016, pp. 103-5). In fact, local intermediaries have always been instrumental in the inculturation of the Catholic faith in Indonesia (Derksen 2014), and have long rallied Catholics to the nationalist cause. Early Catholics created a reputation for scholastic achievement. Pre-independence, Catholics were able to gain some prominence in the public sphere (Rook 2020; Rukiyanto 2019), but their success fuelled tensions with Muslim nationalists (Feener 2017; Ricklefs 2007). After independence was declared in 1945, Catholics were included in the Sukarno regime (Hefner 2017). Later, the authoritarian New Order government of Suharto-which seized power in 1965-regarded Christians and Catholics at first as allies in the battle against communism and the threat posed by political Islam (Larson 2018, p. 177). Later, Muslim lobbying saw the Suharto government ban foreign missionaries from 1975 on. Indonesian Catholicism subsequently became more "home-grown" and even more committed to the nationalist cause (Erb 2006, p. 215).

Today, Indonesian Catholics continue to present as a relatively confident small minority in the public sphere (Steenbrink 2007). From the first appointment of an Indonesian Catholic Bishop in Java in 1940, the connection between being a good patriot and being a good Catholic has been made (Steenbrink 2015). That first Bishop would say to his parishioners: "Be one hundred per cent Catholic and one hundred per cent Indonesian" (Rukiyanto 2019, p. 61). Indonesian Catholic youth activists practice a form of activism close to what we might recognise as liberation theology (Larson 2018). Originally, liberation theology was aimed at dismantling the oligarchic disposition of the Catholic church and redirecting the Catholic lens to the poor and dispossessed. For pro-poor activists, the Bible provided theological material to assemble a strong social justice programme. In Indonesia today, many young Catholics dedicate themselves to good works among the poor (McIntosh 2013). A smaller number follow the path of Catholic activism in the public sphere, targeting their efforts at shoring up the Pancasila constitution, preserving Indonesian democracy and advancing a social justice agenda. Our informants were keen to challenge the anti-democratic Islamist populist push. To do so effectively, they built interfaith coalitions with moderate young Muslims who equally value democracy and religious harmony.

\section{Methodology}

We collected data from 20 Catholic young people in Yogyakarta in 2018/2019. They were active in the public sphere and committed to the cause of nationalist unity. Aged 21-35, there were four females and 16 males, an outcome of the recruitment strategy that purposefully sought young Catholics with an established activist profile. We used the technique of interview with open questions. That interviewing technique encourages free flowing accounts from interviewees (King et al. 2019). Interviews of 30-40 min were conducted and transcribed in Bahasa Indonesia by the second author, who is a native speaker. Transcripts were coded and analysed using a contextualised thematic approach (see Liamputtong 2019). Both authors worked on translation.

Almost all informants had attended a Catholic school, and the majority had a diploma or degree from a Catholic university. In principle, a Catholic education is not just about theology, but encourages students to develop "their gifts and talents"; to make an active contribution to society (Quinn 2018, pp. 71-72). That orientation was evident when informants described their commitment, as young Catholics, to nationalism. Catholics amount to less than five per cent of the population of Yogyakarta (Laksana 2016). Yogyakarta was 
once celebrated as a place of harmony. However, by 2017 it had reached the ranking of least tolerant cities (Carolina 2019; see also Chao 2017; De Jong and Twikromo 2017). Inflamed by Islamist populism, anti-Christian/Catholic violence has increased (Duncan 2013), with multiple attacks in the past decade on Christian and Catholic churches, cemeteries, church services and individuals.

\section{Analysis of Data}

We found that 17 of the 20 interviewees conveyed an identity that synthesised Catholic faith and nationalism, with nationalism ranking more highly. However, it should be borne in mind that our purpose was to interview activist Catholic young people. The young Catholic activists in the Javanese city of Yogyakarta were deeply concerned about the expansion of Islamist political populism, which they tended to describe as a monolithic entity that worked against their interests. In their view, the current Jokowi government only pays lip service to the inclusive multi-faith principle of Pancasila, allowing those of non-Muslim faiths, including Catholics, to be targeted. They feared no genuine attempts were being made to protect their access to opportunities and constitutional status (Mujiburrahman 2006). They perceived the status of their citizenship to be implicitly under threat. The informants said they sometimes felt threatened when attending church services or Catholic organisation meetings, even though they got on well with their Muslim peers and neighbours at the everyday level.

They resented the injustices routinely enacted against Christians and Catholics. For example, many informants mentioned that in 2017 the Christian ex-governor of Jakarta, Basuki Tjahaja Purnama (Ahok), was jailed for blasphemy on a flimsy legal case. Campaigning for re-election in 2016, he told a small audience not to be fooled by those who cite the Qur'an to argue that Muslims should not vote for a non-Muslim leader. Ahok's political opponents operationalised Islamist populism to attack his remarks, including the upload of a heavily edited 13-s clip of his speech to YouTube and other social media. Muslim supporters poured onto the streets and social media was flooded with extremist rhetoric that demanded Ahok be charged, if not executed, for blasphemy (Fanany and Fanany 2021). The young Catholic informants were further scandalised because, on the other side of the coin, the inflammatory rhetoric of popular firebrand preachers like Abdul Somad went unchecked. In 2019, Somad was reported to the police for claiming that any Muslim dying in an Indonesian hospital with crucifixes would go to hell because the crucifix contains a (kafir) jinn - a malign supernatural creature. Yet complaints against that blasphemous claim went nowhere. If anything, Somad has further escalated his attacks on other faiths in Indonesia. They have brought him ever more attention on social media.

\subsection{Pro Ecclesia et Patria}

In interview, the young Catholic activists insisted they were Indonesians first and Catholics second. Rio ( $\mathrm{m}, 24)$ argued that, "if we are just Catholics living in Indonesia, it means that we are not actually Indonesian but just hitchhiking, so for me, I am Indonesian, [then] I am Catholic". ${ }^{3}$ Such statements challenge the centrepiece of the populist Islamist position, that religious identity must come first. Some informants told us they were committed to the nationalist cause precisely because of their Catholic faith. Religious theology was used to make that argument.

For example, speaking in detail about his Catholic patriotism, Astra (m, 25) used the Latin phrase pro ecclesia et patria, "for church and country". Although the familiar phrase mentions the church (ecclesia) first, the use of the copula (et-and) connects ecclesia and patria (nation) as equivalent values; as equally important. Astra was speaking as President of the local branch of PMKRI (Perhimpunan Mahasiswa Katolik Republik Indonesia), the Indonesian Catholic Students Association. Pro ecclesia et patria is the PMKRI motto. Astra was adamant that young Catholics should devote themselves not just to the church, but to the nation. Seminary-trained, Astra's discourse of nationalism synthesised Bible teachings to construct his activist position: 
The Word must become flesh. It's not enough just to pray. It must become flesh, and engage with existing social movements (...) There is nothing in Catholic teachings that is against the Common Good. There is even teaching about the relationship of Church and State. One verse teaches about giving to Caesar what is rightfully that of Caesar. That implies the state, the nation. ${ }^{4}$

Here Astra first cites John 1.14_ "And the Word became flesh and dwelt among us". That verse means the teachings of Jesus should be translated into everyday public life. Astra then cites Matthew 22.21 — "Render unto Caesar the things that are Caesar's, and unto God the things that are God's", a verse that encourages a balanced relationship between religious faith and loyalty to the nation. Lita (f, 22) made the same point as Astra, arguing for the separation of religion and state. She also cited "the verse about giving to Caesar that to which Caesar is entitled", 5 as she called it. The attempt to live out the principle of pro ecclesia et patria aims for a balanced relationship between religious faith and loyalty to the existing (democratic) nation.

Like Astra, Indra $(\mathrm{m}, 28)$ cited the Catholic principle of Common Good-bonum commune. Indra described bonum commune as a concept "born from Catholic thinkers which has made an important contribution to the long-term viability of human society". 6 The concept comes from the writings of the Dominican Friar Thomas Aquinas, in the thirteenth century. For Aquinas, the state creates the "good" of social order. By setting out clear rules of governance, it creates a "common" context for people to flourish and develop, free from the threat of violence and instability. Working for the Common Good is a key tenet of libertarian theology. Both Astra and Sanjaya $(\mathrm{m}, 27)$ made use of bonum commune to explain how Catholic youth could contribute to the forward development of Indonesia. The Pancasila doctrine promotes a productive and orderly governance. Promoting Pancasila as the basis for a democratic Indonesia therefore represents working for the Common Good, as Catholics are meant to do.

Indra, Sanjaya and Astra each cited the historic Three Pledges of Catholic Youth ${ }^{7}$ made in November 1945 after the first declaration of Indonesian independence in August of that year. The three pledges are: 1. Always remain faithful to the leaders of Church and State; 2. Keep fighting for the interests of Church and State; and 3. Always maintain unity, kinship and tolerance. ${ }^{8}$ Indra stated firmly that

From the early days of Indonesia, Catholics have contributed a lot. How? In history, Catholics were right alongside the nation builders Sukarno and Hatta. They have also been active in nature conservation. Catholics are very much involved in shaping the identity of our nation. ${ }^{9}$

Ganjar ( $m$, 35) summed up the typical young Catholic activist position, "Through the wisdom of Jesus, I locate myself where I am. That means I am Indonesian and [then] I am Catholic". ${ }^{10}$ Ganjar had political ambitions. He did not think being Catholic would prove an obstacle. He said, "having received the sacrament of confirmation, I am ready. Ready in faith and ready to work for the country, the nation". ${ }^{11}$ Catholics believe that confirmation is the sacrament by which they receive a special outpouring of the Holy Spirit. It endows them with an increased ability to practise their Catholic faith in every aspect of their lives. Taken together, nationalism and Catholicism constitute a strong identity claim, one which prioritises the social progress of the nation. The young activists in Yogyakarta were prepared, as committed Catholics, to ensure nationalist goals by protecting Pancasila.

\subsection{Protecting Pancasila}

The Indonesian national slogan "Bhinekka Tunggal Ika" [Out of many, one], embodies the concept of unity in diversity (Mulyatno 2019, p. 129). That concept was highly valued by the informants. Facing the threat of Islamist populism, iteration of the Pancasila doctrine expressed their committed national identity as young Catholics. They saw a match between their faith and Pancasila. Dobie (m, 28) explained that, "it's about togetherness, justice, unity. That's in both Pancasila and in Catholicism; not only in one of them". ${ }^{12}$ Hasto $(\mathrm{m}, 26)$ compared the five principles of Pancasila directly to the Ten Commandments in 
the Bible, while Andre (m, 22) thought Pancasila ideally reflected the work of Catholics "who strive to do good in the community, in the service of God". ${ }^{13}$ Indra stated, "we support Pancasila as the basis of a state that can support Catholic interests". He added, practically, that "without Pancasila, it seems like Catholics will be crushed". ${ }^{14}$ Mela (f, 21) concurred. She maintained that it was all about values. She compared Pancasila directly to Catholicism, "the values of Pancasila are evident, such as helping each other; that upholds and emphasises democratic ideology". ${ }^{15}$ Lita (f, 22) went through each principle (sila) of the Pancasila doctrine to show how it matched Catholic values:

The first principle [One God] clearly matches. The second principle of humanity is also in line with Catholicism. The unity of Indonesia is also in line [with Catholic values], and the fourth principle [democracy] also lines up. The fifth aligning principle is, of course, social justice. So, I conclude that it all fits. ${ }^{16}$

However, that kind of resonance is not just claimed by Indonesian Catholics. It is also claimed by many followers of Islam in Indonesia (see Suryadinata 2018). For example, the moderate Muslim organisation Nahdlatul Ulama readily acknowledges that Pancasila shows affinity with Islamic principles. The young Catholic activists were aware of that. Dito (m, 21) said, "I do not challenge the idea that Pancasila matches the spirit of Islam, nor that it is in keeping with the verses of the Qur'an". ${ }^{17}$ In other words, he recognises that Pancasila implicitly forges a common cause between Catholic and (moderate) Muslim youth activists. Both theocratic traditions value unity and harmony in the nation and rationalise those values using holy scriptures.

Pancasila has long been venerated in Indonesian Catholicism. For the mid-twentieth century Catholic leader Y.B. Mangunwijaya (Romo Mangun), Pancasila was not an abstract value, but a productive force that encouraged young Catholics to grow up understanding themselves as Indonesians. In 2016 the Archdiocese of Jakarta launched a five-year campaign called "Amalkan Pancasila" [Practice Pancasila] to sheet home the political responsibility of Catholic citizens in the Indonesian nation (Rook 2020, p. 239). In 2017, at the Seventh Catholic Asian Youth Day (AYD) in Yogyakarta, a Catholic youth choir of more than 500 performed an arrangement by a Catholic composer of the Indonesian patriotic song "Indonesia Jaya", which includes lyrics praising Pancasila and national unity. During the instrumental interlude, choir members shouted "Saya Indonesia; Saya Pancasila!" [I am Indonesia; I am Pancasila], waving small Indonesian flags. In fact, the chant of the young choristers echoed events earlier that year after President Jokowi decreed that Hari Lahir Pancasila [Pancasila Birthday] was to be celebrated as a national holiday every year (Rook 2020, p. 235).

Pancasila was construed by the informants to represent everything good about Indonesia, "Pancasila values are also the values of the bible and God's teachings. If we look at the broad doctrinal outlines, love is in the Pancasila"18 (Yusuf, m, 25). However, that claim has to be ratified against the contradiction between the hierarchical authority of Catholicism and Indonesian democracy:

Is the Catholic church a democratic institution? The answer is, in principle, no. Right? It's really a kind of monarchy. Not absolute, something a bit softer. But when it comes to the practice of Pancasila, then Catholic values are very very compatible (Yusuf).

In the Roman Catholic Church, authority comes down the line from the Pope himself through hierarchically stratified layers of the ordained clergy down to the laity. The Pope rules the church worldwide in much the same way as a king leads a country, and he is the head of state for the Vatican. Yet Catholic social teaching promotes democratic principles such that, "all human beings are acknowledged as having the same fundamental worth and deserve the same protection of basic rights" (Himes 2019, p. 305). That is, God's love extends equally to all. In other words, Yusuf was prepared to regard the institutional structure of the Catholic Church and its social justice values separately to support his conviction that Pancasila and Catholic principles are on the same page. Yet Pancasila is an 
abstract set of ideas. While in theory it promotes Indonesia's ethnic and religious diversity, it can be appropriated for political ends.

There has been much criticism of a recent move by the ruling Indonesian Democratic Party of Struggle (PDI- $\mathrm{P}^{19}$ ) to introduce a bill proposing strict guidelines for interpreting Pancasila. The PDI-P Jokowi government would use the bill to disseminate the "proper" interpretation of Pancasila ideology at all levels of society to subdue the influence of Islamist populism. Yet the formulation of a strict interpretation of Pancasila means it could be used to politically attack almost any oppositional group as anti-Pancasila (see Iskander 2016), thereby threatening the democratic process. As a political activist, Nuel (m, 21) was very much aware of that danger, even though he could see the point of the bill:

Catholics in Yogyakarta are very pro-PDIP. [Yet] if Pancasila becomes a political sledgehammer then what was Pancasila in the first place? You see, if Pancasila is treated as a single ideology, the main truth, then it silences others. All along Pancasila has been used for political purposes. Jokowi's Pancasila [bill] means that anyone outside that version of Pancasila is not with Jokowi. Pancasila has been narrowed to serve his political interests. I see that endangering democratic conditions in the future. ${ }^{20}$

Richard $(m, 23)$ felt the worst excesses of Islamist populism would be better challenged by him and his friends "showing the spirit of love to empower people, demonstrating our positive Catholic identity through strategic action". ${ }^{21}$ One important strategy was to build an interfaith bridge with young Muslim activists.

\subsection{Finding Common Cause with Muslim Youth}

Seminary graduate Yusuf $(m, 25)$ was running a café hosting political discussions about nationhood for young people of all faiths. He spoke about living the Catholic theological principle of duc in altum. Duc in altum (Latin) means to put out into the deep. In the Bible, they are the words that Jesus said to Peter when they first met. Jesus was urging Peter to go into deep water and lower his nets to get a catch. The phrase symbolises exploring the depth of the Catholic faith. Clearly, Yusuf felt that he was purposefully expanding the discourse of youth nationalism through encouraging interfaith dialogue.

Doni agreed with the strategy of building bridges, pointing out that, "as a minority, we have to work hand in hand ... No longer can we be alone [in the nationalist struggle]". 22 Catholics are indeed a tiny minority of the Indonesian population. Alone, they cannot expect to make an impact. One strategy is to band together with moderate Muslim youth and create pro-citizenship campaigns online and on the street to counter the influence of Islamist populism. That tactic further signifies the refusal of primordial populist thinking in the nation.

The young Catholic activists in Yogyakarta had worked to create such political alliances. For example, Sanjaya $(\mathrm{m}, 27)$ spoke about solidarity between young Catholics and "our friends in Nahdlatul Ulama, whose [inclusive] motto is Islam Nusantara. When things happen, in times of need, we always stand together". ${ }^{23}$. Despite the existence of some quite conservative factions, in general Nahdlatul Ulama (NU) advocates Islam Nusantara (Islam of Indonesia). In short, NU promotes moderation, compassion, inclusiveness and tolerance (see Wahid 2011). Around Central Java, local NU groups have actively engaged in dialogue with Christian and Catholic faiths, with the shared goal of increasing social harmony. NU youth wing members have provided security for major Catholic church services in Yogyakarta since 2017. Frequent meetings and forums are held to express political solidarity with non-Muslims against the populist Islamist push.

Yusuf felt such inter-faith alliances flowed naturally because the problem of religious intolerance did not happen at the social level between him and his Muslim friends. "There is nothing wrong with me and the young people around me. When we all come together as friends we can discuss issues like whether or not they can wish us Merry Christmas or not, and how to respond in a cool-headed way". ${ }^{24}$ Yuli $(f, 28)$ felt the same about her Muslim peers: 
When it comes to friends, there is no problem between us. We respect each other. We have the same attitude of respect for those whose religion is different from ourselves. We put ourselves in the place of those who are different from us and we give them respect. When it comes to worship, you know, I worship in my way, you worship in your way. ${ }^{25}$

Mela (f, 21) explained that constructive dialogue flowed readily because, as Indonesians, both Catholic and Muslim young people value the local cultural tradition of musyawarah (deliberative discussion/mediation). She said, "[you can have] musyawarah like that when you gather with different people". ${ }^{26}$ In musyawarah, parties set aside their interests so as to reach an amicable settlement on an issue or dispute (Syukur and Bagshaw 2018 , p. 14). Referring once again to the ancient tradition of musyawarah, she emphasises the shared national culture over the primordial religious identity claims that fuel Islamist populism.

Despite the threat posed by Islamist populism, recent research in Indonesia indicates that adjacently-located members of different religions are constantly interacting with each other, and thereby actually living the practice of a religiously plural nation (Rook 2020; Laksana and Wood 2019). For instance, Nugroho studied young Indonesians imagining the nation in ethnically distinct, low SES, Christian-majority Kupang, which is a long way east from Muslim-dominated Java and the economically thriving capital Jakarta, in the west. She found that young people in Kupang did not see Indonesia as held together by shared characteristics of language, culture and physical appearance, and certainly not by religion. Rather, they demonstrated an instrumental approach toward nationhood, one that emphasised harmonious integration to shore up the prospect of future prosperity for their region and themselves (Nugroho 2020, p. 89).

Young Catholic and moderate Muslim activists in Yogyakarta are no different in that respect. Doni reflected on the fact that

Everyone needs to work; to live; and to express their opinions peacefully and safely. Because of course life in the future for young people in Indonesia is going to become more difficult. It will be harder to find a job; and harder to create a business. $^{27}$

Thus, he argued, young Indonesians need to create solidarity to ensure the nation is not fragmented and fractured by primordial claims encouraged by populist political actors who seek to use the thin ideology of religious supremacy for their own political ends.

\section{Discussion}

Our analysis illustrates an intriguing way in which the Islamist populist push to narrow public opportunities for non-Muslims is challenged by young Indonesians committed to the ideals of Pancasila and democracy. The findings are notable because they point to an actively-sought strategic alliance between Catholic and Muslim youth at the grassroots level to consolidate a unified, harmonious and prosperous nation. The informants perceived Pancasila to be a symbolic rallying point for counter-populist mobilisation by young Catholics and their Muslim allies. This is particularly important in light of the democratic decline in Indonesia identified by Mietzner (2020). When properly applied, the principles of Pancasila make it possible to hold government officials "accountable" in the face of Islamist populist-driven claims for the restriction of non-Muslims (Rook 2020, p. 258).

Some informants referenced Catholic theological precepts in framing their pro-nationalist activism, actively synthesising Catholicism and a fervent nationalism. At the same time, they were well aware of moderate Muslim claims of a similarly theological nature. Mass Muslim organisations such as NU defend the accommodation between Islam and democracy in the pluralist nation, referencing Qu'ranic verses. As Menchik (2019, p. 417) observes, at present, "NU and Muhammadiyah see the material and ideological interests of the Muslim community as being served by democracy". The abandonment of the secular Indonesian constitution in favour of an Islamic state would be a grim prospect for Indonesians of other faiths, implying exclusion or conversion. Yet it would also be disastrous for the many, many 
millions of Indonesian Muslims who do not wish to live under that kind of governance structure. As Bayat (2007, p. 9) points out, in the Middle East, the introduction of Islamist rule has often faced crises when put into practice. Young Indonesians of all faiths want to be able to look forward to a prosperous future for themselves and the families that they will create.

\section{Conclusions}

This paper has reported data from young Catholic activists concerned about the perceived dangers of growing Islamist populism in Indonesia. The informants spoke of building inter-faith coalitions with local moderate Muslim youth groups and with Nahdlatul Ulama, the largest independent Islamic organisation in the world. We see in the interview citations above the depth of nationalist feeling and the commitment to interfaith bridge building among young Catholics. To make those bridges effective and strong, they scaffold from the liberation theology precepts of their own faith to the theologically supported position of moderate Muslims who also value democracy and the existing national constitution. Young Catholic activists in Indonesia may well be encouraged by the publication, on 3 October 2020, of Pope Francis' second encyclical, Fratelli tutti, on the theme of "fraternity and social friendship". In that letter of guidance Pope Francis calls on the faithful to be oriented toward the long-term common good, and to seek convergence on important issues with people of other faiths.

We know from Bayat (2007) that the characteristics of Islamist populism differ from country to country, depending on political structures and historical events. The theocratic populism surging in Indonesia at present is, as Eddyono (2020) argues, an ummah-centred nationalism. Young pro-democracy activists of Muslim and Catholic faiths favour, in contrast, a distinctive citizen-centred nationalism, one which promotes the idea of active citizens who harmoniously exercise their rights and obligations. Their view of nationalism emphasises the state's obligation towards all of its citizens.

Author Contributions: Conceptualization, G.R.W. and P.N.; methodology, P.N. and G.R.W.; formal analysis, P.N.; investigation, G.R.W.; resources, G.R.W.; writing-original draft preparation, P.N.; writing-review and editing, P.N.; project administration, G.R.W. (Indonesia) and P.N. (Australia). All authors have read and agreed to the published version of the manuscript.

Funding: This research received no external funding.

Institutional Review Board Statement: The protocol for this study was reviewed by the Human Research Ethics Committee (HREC) of the University of Newcastle (UoN), Australia in September 2019. The study was approved with Reference No: H-2019-0247 on 29 September 2019.

Informed Consent Statement: According to the study protocol approved by UoN HREC on 29 September 2019, written informed consent for interview was obtained from all informants involved in the study. Written informed consent for publication was obtained from informants at the same time. All participants are anonymised.

Data Availability Statement: Data supporting reported results can be found by contacting the authors who conducted the study.

Conflicts of Interest: The authors declare no conflict of interest.

\section{Notes}

1 Shi'ite Muslims are only a tiny minority in Indonesia, but viewed in highly negative terms. Ahmadiyah Muslims are often regarded as heretical. Sufism may be regarded with suspicion. For brevity, I use the terms Muslim and Islam to refer to Sunni Islam.

2 Pancasila combines two Sanskrit words, "panca" - five and "sila"-principles. The five principles are intended to enshrine democracy, social justice and monotheism.

3 Kalau kita orang katholik yang hidup di Indonesia rarti sebenarnya bukan orang Indonesia tapi cuma numpang aja, jadi aku orang Indonesia aku beragama katholik.

4 [Menjadi katolik itu kan tidak hanya kamu harus mengurusi doa saja]. Tapi bagaimana sabda itu harus menjadi daging. Tidak cukup hanya berdoa saja. Tapi harus menjadi daging, dengan Gerakan-gerakan sosial yang ada ( ... ) Tidak ada dalam gereja 
katolik itu ajaran anda diajari untuk menentang kebaikan Bersama. Pun bagaimana relasi gereja pada negara. Ayatnya berikan apa yang menjadi hak kaisar. Maksudnya ya negara ya negara begitu.

5 Juga yang ayat berikan pada kaisar yang menjadi hak kaisar.

6 Bonum komuni, sebuah konsep yang dilahirkan dari para pemikir gereja, yang menjadi sumbangan penting untuk keberlangsungan hidup masyarakat secara umum.

7 Tri Prasetya Pemuda Katolik.

8 See https://pemudakatolik.or.id (accessed 8 August 2020).

9 Sejak ada Indonesia, Orang katholik sudah memyumbang banyak. Dan gimana ya. Ya sejarah Indonesia memperlihatkan orang-orang yang bersama Soekarno dan Hatta juga banyak orang katholik, mereka bekerja di Lini yan lain dan ikut membentuk identitas bangsa juga.

10 Dengan kecerdikan yesus, bahwa, saya harus bisa menempatkan posisi dimana saya berada. Artinya bahwa, aku yo wong indonesia, aku yo wong katolik.

11 Sudah terima sakramen penguatan, kita siap. Secara iman ya, tapi secara negara, ya, saya siap harus bernegara, berbangsa.

12 Ya kebersamaan, keadilan, persatuan. Itu kan ada di pancasila dan di katolik; enggak hanya di salah satunya.

13 Kalau dilihat dari maksudnya Pancasila ya sejalan dengan Katholik yang berusaha memikirkan kebaikan bersama untuk Ketuhanan.

14 Kita mendukung pancasila sebagai dasar negara yang dapat mendukung kepentingan katholik. Tanpa Pancasila, sepertinya Katholik akan dilibas.

15 Nilai nilai demokrasi Pancasila kayak saling tolong menolong menjunjung tinggi ideologi jadi tuh kayak mulai kelihatan.

16 Kalo sila pertama jelas masuk sih. Kalau sila kedua kemanusiaan juga selaras dengan katolik. Kalau persatuan Indonesia juga sejalan, sila ke empat juga sejalan, sila ke lima juga tentu saja soal keadilan sosial itu juga masuk banget. Jadi kesimpulannya sejalan sih mas.

17 Saya tidak menyalahkan bahwa Pancasila diklaim berasal dari Islam entah mengikuti ayat Al-quran.

18 Nilai-nilai yang ada di pancasila itu. Karena itu nilai2 yang terkandung di alkitab juga, di ajaran tuhan juga. Kalo kita ambil garis besarnya ya cinta kasih itu Pancasila.

19 PDI-P is the political party of the current President of Indonesia, Joko Widodo, or Jokowi. PDI-P is currently led by Megawati Sukarnoputri, who was president of Indonesia from 2001 to 2004. Megawati is the daughter of Sukarno, the first president of Indonesia and an architect of the Pancasila doctrine.

20 Katolik Jogja sangat PDIP sekali, sangat merah sekali. Artinya, ee, melihat Pancasila bisa saja menjadi palu godam dengan apa dulu menempatkan Pancasila? Ya kalau Pancasila itu semacam ideologi tunggal dan itu menjadi kebenaran utama ini saya pikir bisa mematikan yang lain. Kelihatannya selama ini kan Pancasila itu dipakai untuk kepentingan politik. Yang Pancasila Jokowi, yang di luar Pancasila itu bukan Jokowi. Jadi Pancasila dibuat jadi sempit untuk kepentingan politik begitu. Dan itu yang saya lihat membahayakan kondisi demokrasi ke depan.

21 Ya dengan membawa cinta kasih dalam pengabdian masyarakat dengan membawa identitas katholik kita, dengan melakukan berbagai macam program kerja tadi.

22 Sebagai minoritas, kita harus saling bahu-membahu ... Enggak bisa lagi sendiri-sendiri.

23 Dari teman-teman Nahdatul Ulama, dengan tag line Islam Nusantara. Nah hal-hal semacam ini, yang perlu, kita gandeng terus.

24 Nggak ada salahnya dari diriku sendiri aja dan orang-orang di sekitarku mungkin karena kita di sini juga diskusi sama temen ya kasih ucapan natal aja kok enggak boleh, Gimana caranya kita tanggapi dengan cara yang menyejukkan.

25 Tapi kalo untuk temen sesama temen, kayanya ngga. Kita saling menghargai kalo, kayanya kalo untuk cara pandang menghargai sama yang beda agama itu dari kitanya sendiri deh. Gimana kita menempatkan diri kepada mereka yang berbeda, dan begitu juga dengan mereka yang berbeda dengan kita, kan menghargai kita juga. Kalo ada ibadah, yaudah, kamu menjalankan ibadahmu, saya juga menjalankan ibadah saya.

26 Bermusyawarah kayak ya itu ketika berkumpul dengan oranmg orang yang berbeda itu.

27 Supaya setiap orang bisa bekerja; bisa hidup; dan mengekspresikan pendapatnya dengan damai dan aman. Karna tentu hidup ke depan bagi anak muda makin sulit. Pasti lebih sulit lagi cari pekerjaan; dan lebih susah juga untuk bikin usaha.

\section{References}

Arifianto, Alexander. 2009. Explaining the Cause of Muslim-Christian Conflicts in Indonesia: Tracing the Origins of Kristenisasi and Islamisasi. Islam and Christian-Muslim Relations 20: 73-89. [CrossRef]

Aspinall, Edward. 2015. The Surprising Democratic Behemoth: Indonesia in Comparative Asian Perspective. Journal of Asian Studies 74: 880-902. [CrossRef]

Azra, Azyumardi. 2020. Understanding Indonesia's 'Third Way Islam'. In Wars of Ideas: Theology, Interpretation and Power in the Muslim World. Edited by Ilhan Berman. Lanham: Rowman and Littlefield, pp. 73-86.

Bayat, Assef. 2007. Making Islam Democratic: Social Movements and the Post-Islamist Turn. Stanford: Stanford University Press.

Brown, Bernardo, and Claire Thi Liên Tran. 2020. Introduction: Global Catholicism in Southeast Asia: Mobilities and Networks. Sojourn: Journal of Social Issues in Southeast Asia 35: 197-216. [CrossRef] 
Carolina, Juke. 2019. This Region of Indonesia Was Known for its Religious Harmony. Now, Catholics Face Growing Intolerance. GlobalPost, June 27. Available online: https://www.pri.org/stories/2019-06-27/region-indonesia-was-known-its-religiousharmony-now-catholics-face-growing (accessed on 17 July 2019).

Chao, En-Chieh. 2017. Entangled Pieties: Muslim-Christian Relations and Gendered Sociality in Java. London: Palgrave Macmillan.

Chaplin, Chris. 2018. Salafi Islamic Piety as Civic Activism: Wahdah Islamiyah and Differentiated Citizenship in Indonesia. Citizenship Studies 22: 208-23. [CrossRef]

Chong, Wu-Ling. 2018. Chinese Indonesians in Post-Suharto Indonesia. Hong Kong: Hong Kong University Press.

De Jong, Edwin, and Argo Twikromo. 2017. Friction within Harmony: Everyday Dynamics and the Negotiation of Diversity in Yogyakarta, Indonesia. Journal of Southeast Asian Studies 48: 71-90. [CrossRef]

Derksen, Maaike. 2014. 'On Their Javanese Sprout We Need to Graft the European Civilisation'; Fashioning Local Intermediaries in the Dutch Catholic Mission, 1900-1942. Tijdschrift voor Genderstudies 19: 29-55. [CrossRef]

Duncan, Christopher R. 2013. Violence and Vengeance: Religious Conflict and Its Aftermath in Eastern Indonesia. Ithaca: Cornell University Press.

Eddyono, Suzanna. 2020. Competing Nationalisms in Post-New Order Indonesia. Nationalism and Ethnic Politics 26: 421-39. [CrossRef]

Erb, Maribeth. 2006. Between Empowerment and Power: The Rise of the Self-Supporting Church in Western Flores, Eastern Indonesia. Sojourn: Journal of Social Issues in Southeast Asia 21: 204-29. [CrossRef]

Fanany, Ismet, and Rebecca Fanany. 2021. Religion and Populism: The AKSI 212 Movement in Indonesia. In Populism, Democracy and Community Development. Edited by Sue Kenny, Jim Ife and Peter Westoby. Bristol: Policy Press, pp. 245-58.

Feener, R. Michael. 2017. Religious Competition and Conflict over the Longue Durée: Christianity and Islam in the Indonesian Archipelago. Asian Journal of Religion and Society 5: 1-22.

Hadiz, Vedi. 2018. Imagine All the People? Mobilising Islamic Populism for Right-Wing Politics in Indonesia. Journal of Contemporary Asia 48: 566-83. [CrossRef]

Haq, Muhammad N. 2021. Patronizing the Mass: How Middle-Agents Deepened Populism and Post-Truth in Indonesia 2019 Presiden-tial Election. Jurnal Politik 7: 75-103.

Hariyadi, Mathias. 2019. 'Halal' Tourism on Flores, a Provocation for Officials and Catholics. AsiaNews.it, July 5. Available online: http: / / www.asianews.it/news-en /\%27Halal \T1 \textquoteright-tourism-on-Flores,-a-provocation-for-officials-andCatholics-46950.html (accessed on 6 April 2020).

Harsono, Andreas. 2019. Race, Islam and Power: Ethnic and Religious Violence in Post-Suharto Indonesia. Clayton: Monash University Publishing.

Hefner, Robert W. 2011. Where Have All the Abangan Gone? Religionization and the Decline of Non-Standard Islam in Contemporary Indonesia. In The Politics of Religion in Indonesia: Syncretism, Orthodoxy, and Religious Contention in Java and Bali. Edited by Michel Picard and Remy Madinier. New York and London: Routledge, pp. 71-91.

Hefner, Robert W. 2017. Christians, Conflict, and Citizenship in Muslim-Majority Indonesia. The Review of Faith and International Affairs 15: 91-101. [CrossRef]

Hefner, Robert W. 2020. Islam and Covenantal Pluralism in Indonesia: A Critical Juncture Analysis. The Review of Faith \& International Affairs 18: 1-17.

Himes, Kenneth. 2019. Catholic social teaching, economic inequality, and American society. Journal of Religious Ethics 47: 283-310. [CrossRef]

IndexMundi. 2019. Indonesia. Available online: https:/ /www.indexmundi.com/indonesia/ (accessed on 20 March 2020).

Iskander, Pranoto. 2016. The Pancasila Delusion. Journal of Contemporary Asia 46: 723-35. [CrossRef]

King, Nigel, Christine Horrocks, and Joanna Brooks. 2019. Interviews in Qualitative Research. London: Sage.

Laksana, Albertus Bagus. 2015. Love of Religion, Love of Nation: Catholic Mission and the Idea of Indonesian Nationalism. Kritika Kultura 25: 91-112. [CrossRef]

Laksana, Albertus Bagus. 2016. Muslim and Catholic Pilgrimage Practices: Explorations through Java. London: Routledge.

Laksana, Albertus Bagus. 2018. The Pain of Being Hybrid: Catholic Writers and Political Islam in Postcolonial Indonesia. International Journal of Asian Christianity 1: 225-49. [CrossRef]

Laksana, Ben K. C., and Bronwyn Wood. 2019. Navigating Religious Diversity: Exploring Young People's Lived Religious Citizenship in Indonesia. Journal of Youth Studies 22: 807-23. [CrossRef]

Larson, Erica. 2018. Developing Faith and Character to Develop the Nation: Perspectives from an Elite Indonesian Catholic School. In The Mission of Development: Religion and Techno-Politics in Asia. Edited by Catherine Scheer, Phillip Fountain and R. Michael Feener. Leiden: Brill, pp. 165-89.

Liamputtong, Pranee. 2019. Qualitative Research Methods, 5th ed. Oxford: OUP.

Lim, Merlyna. 2017. Freedom to Hate: Social Media, Algorithmic Enclaves, and the Rise of Tribal Nationalism in Indonesia. Critical Asian Studies 49: 411-27. [CrossRef]

Liow, Joseph. 2016. Religion and Nationalism in Southeast Asia. Cambridge: Cambridge University Press.

Marshall, Paul. 2018. The Ambiguities of Religious Freedom in Indonesia. The Review of Faith and International Affairs 16: 85-96. [CrossRef]

McIntosh, Alastair. 2013. Can Liberation Theology Serve Indonesia? Semper Reformanda and the Spiritual Challenges of our Times. Sola Experentia 1: 121-236. 
Menchik, Jeremy. 2017. Islam and Democracy in Indonesia: Tolerance without Liberalism. Cambridge: Cambridge University Press.

Menchik, Jeremy. 2019. Moderate Muslims and Democratic Breakdown in Indonesia. Asian Studies Review 43: 415-33. [CrossRef]

Mietzner, Marcus, and Burhanuddin Muhtadi. 2019. The Mobilisation of Intolerance and its Trajectories: Indonesian Muslims' Views of Religious Minorities and Ethnic Chinese. In Contentious Belonging: The Place of Minorities in Indonesia. Edited by Greg Fealy and Ronit Ricci. Singapore: Institute for Southeast Asian Studies, pp. 155-74.

Mietzner, Marcus. 2020. Populist Anti-Scientism, Religious Polarisation, and Institutionalised Corruption: How Indonesia's Democratic Decline Shaped Its COVID-19 Response. Journal of Current Southeast Asian Affairs 39: 227-49. [CrossRef]

Mudde, Cas, and Cristóbal Kaltwasser. 2017. Populism: A Very Short Introduction. Oxford: OUP.

Mujiburrahman. 2006. Feeling Threatened: Muslim-Christian Relations in Indonesia's New Order. Amsterdam: Amsterdam University Press. Müller, Jan-Werner. 2021. What Is Populism? Philadelphia: University of Pennsylvania Press.

Mulyatno, Carolus Borromeus. 2019. Theology of Independence as a Foundation of Developing Catholic Education in Indonesian Context According to Y. B. Mangunwijaya. Journal of Asian Orientation in Theology 1: 119-38.

Nugroho, Stefani. 2020. The Divergent Nation of Indonesia: Heterogeneous Imaginings in Jakarta, Kupang, and Banda Aceh. Singapore: Springer.

Pedersen, Lene. 2016. Religious Pluralism in Indonesia. Asia Pacific Journal of Anthropology 17: 387-98. [CrossRef]

Pektas, Serafettin. 2021. A Comparative Analysis of Three Sunni Muslim Organizations on 'Moderate' and 'Radical' Islam in Egypt, Morocco and Indonesia. Religion 51: 190-213. [CrossRef]

Pepinsky, Thomas, R. William Liddle, and Saiful Mujani. 2018. Piety and Public Opinion: Understanding Indonesian Islam. New York: Oxford University Press.

Postill, John. 2018. Populism and Social Media: A Global Perspective. Media, Culture E Society 40: 754-65.

Power, Thomas. 2018. Jokowi's Authoritarian Turn and Indonesia's Democratic Decline. Bulletin of Indonesian Economic Studies 54: 307-38. [CrossRef]

Quinn, Brandy P. 2018. Purposeful Explorers: Adolescents Finding Their Purposes in a Catholic High School. Journal of Catholic Education 21: 53-75. [CrossRef]

Ricklefs, Merle. 2007. Polarising Javanese Society: Islamic and other Visions c. 1830-1930. Singapore: National University of Singapore Press.

Rook, Emilie. 2020. Complex Centers and Powerful Peripheries: Catholicism, Music, and Identity Politics in Indonesia. Unpublished Ph.D. thesis, University of Pittsburgh, Pittsburgh, PA, USA.

Rukiyanto, B. Agus. 2019. Inculturation in the Catholic Church of Indonesia. Journal of Asian Orientation in Theology 1: 49-80.

Salmela, Mikko, and Christian Von Scheve. 2017. Emotional Roots of Right-Wing Political Populism. Social Science Information 56: 567-95. [CrossRef]

Schmidt, Leonie. 2021. Aesthetics of Authority: 'Islam Nusantara' and Islamic 'Radicalism' in Indonesian Film and Social Media. Religion 51: 237-58. [CrossRef]

Soeriaatmadja, Wahjudi. 2021. Indonesia Bans Schools from Forcing Students, Teachers to Don Muslim Headscarf. The Straits Times, February 6. Available online: https:/ /www.straitstimes.com/asia/se-asia/indonesia-bans-schools-from-forcing-studentsteachers-to-don-muslim-headscarf (accessed on 6 February 2021).

Steenbrink, Karel. 2007. Catholics in Indonesia. Volume 2: The Spectacular Growth of a Self-Confident Minority, 1903-1942. Leiden: Brill.

Steenbrink, Karel. 2015. Catholics in Independent Indonesia: 1945-2010. Leiden: Brill.

Suryadinata, Leo. 2018. Pancasila and the Challenge of Political Islam: Past and Present. Singapore: ISEAS Publishing.

Syarif, Zainuddin, and Abd Hannan. 2020. Islamic Populism Politics and its Threat to Indonesian Democracy. Al-Tahrir 20: 251-77.

Syukur, Fatahillah, and Dale Bagshaw. 2018. Indonesia: The Role of the Traditional, Indigenous Musyawarah Mufakat Process of Mediation. In Conflict Resolution in Asia: Mediation and Other Cultural Models. Edited by Stephanie P. Stobbe. New York: Lexington, pp. 13-34.

Van Bruinessen, Martin. 2018. Indonesian Muslims in a Globalising World: Westernisation, Arabisation and Indigenous Responses. Singapore: S. Rajaratman School of International Studies.

Van Klinken, Gerry. 1997. Power, Symbol and the Catholic Mission in Java: The Biography of Frans van Lith, SJ. Documentieblad voor de Geschiedenis van de NederlandseZending en Overzeese Kerken 1: 43-59.

Vickers, Adrian. 2013. A History of Modern Indonesia, 2nd ed. Cambridge: CUP.

Wahid, Abdurrahman. 2011. The Illusion of an Islamic State. Winston-Salem: LibForAll Foundation.

Yilmaz, Ihsan, and Nicholas Morieson. 2021. A Systematic Literature Review of Populism, Religion and Emotions. Religions 12: 272. [CrossRef]

Yulisman, Linda. 2019. Indonesia aims to expand economy by 5.3\% in 2020. The Straits Times, August 17 . Available online: https:/ / www.straitstimes.com/asia/se-asia/indonesia-aims-to-expand-economy-by-53-in-2020 (accessed on 18 August 2019). 